\title{
Aktivitas Enzim Peroksidase Daun Planlet Pisang Ketan (Musa paradisiaca L.) Hasil Pengimbasan Ketahanan terhadap Asam Salisilat secara In Vitro
}

\section{Peroxidase Enzyme Activity of Leaves of Banana Ketan Plantlet (Musa paradisiaca L.) Results of Induced Resistance of The In Vitro Salicylic Acid}

\section{Imamah Muslimah*, Endang Nurcahyani, dan Zulkifli}

Jurusan Biologi FMIPA Universitas Lampung, Bandar Lampung, Indonesia J1. Prof. Dr. Soemantri Brojonegoro No. 1, Bandar Lampung, Indonesia 35145 email: imamahmuslimah0405@gmail.com

\begin{abstract}
Banana plant production are decreased because it getting an attack from Fusarium oxysporum. "ketan" Banana plantlet that resistant to the Fusarium oxysporum were selected by in vitro in the solid Murashige and Skoog (MS) medium with added salicylic acid at 40 ppm, $50 \mathrm{ppm}, 60 \mathrm{ppm}$, and 70 ppm concentration, compared with controls (0 ppm). The aim of this research is to determine the activity of peroxidase enzyme on leaves of banana ketan plantlet. The research was carried out in December 2015 to February 2016 in the Laboratory of Botani (in vitro room), Departement of Biology, Faculty of MIPA, Lampung University. This study used a completely randomized design with 5 replications. Data were analyzed with the variance (Anova) and if them different will be continued by LSD test performed at 5\% significance level. Extraction of peroxidase method using Saravanan et al. (2004) with the mixture of pyrogallol and $\mathrm{H}_{2} \mathrm{O}_{2}$. The absorbance was measured with a spectrophotometer (Shimudzu UV 800) at wavelength ( $\lambda$ ) of $420 \mathrm{~nm}$ and readable from zero. The result showed that the activity of peroxidase enzyme on the leaves banana ketan plantlet has increased optimally in the salicylic acid concentration of 50 ppm compared with controls. Increased of Peroxidase enzyme activity showed that banana ketan plantlet was resistant to the salicylic acid and expected to be resistant to Fusarium oxysporum.
\end{abstract}

Keywords: Salicylic acid, Peroxidase enzyme, Fusarium oxysporum, in vitro, Banana ketan

Diterima : 18 Agustus 2016, Disetujui : 20 juli 2017

\section{PENDAHULUAN}

Pisang merupakan bahan pangan ke empat terpenting di dunia setelah beras, susu, dan gandum (Megia, 2005). Selain itu, pisang menjadi komoditas buah tropis yang sangat populer di dunia karena rasanya lezat, kandungan gizi tinggi, dan harga relatif murah (Sunarjono, 2004). Salah satu satu jenis pisang yang unggul di Indonesia yaitu pisang ketan (Mulyani et al., 2008).

Kendala utama yang sering dihadapi oleh petani pisang Indonesia yaitu layu fusarium yang disebabkan oleh Fusarium oxysporum f.sp cubense (Foc) (Dimyati et al., 2000). Fusarium oxysporum merupakan jamur yang bersifat tular tanah (soil- borne pathogen). Jamur ini dapat menular melalui tanah atau dari tanaman sakit lain dan menginfeksi tanaman melalui luka pada akar sehingga menyebabkan penyakit layu (Semangun, 1989). 
Salah satu alternatif yang efisien dan efektif untuk mengendalikan jamur Fusarium oxysporum yaitu penggunaan varietas yang tahan (Nurcahyani, 2014). Pengembangan kultivar tahan Fusarium oxysporum dapat dilakukan menggunakan metode seleksi in vitro (Suryanti et al., 2009) yaitu seleksi yang dilakukan terhadap eksplan pada kultur in vitro menggunakan elisitor (Predieri, 2001). Berdasarkan hal tersebut di atas, maka dilakukan pengujian ketahanan pisang terhadap Foc dengan penambahan asam salisilat pada konsentrasi berbeda. Penelitian ini bertujuan untuk mengetahui dan menganalisis karakter ekspresi yang spesifik pada planlet pisang ketan tahan asam salisilat secara in vitro yaitu kandungan enzim peroksidase.

\section{METODE}

Penelitian ini dilaksanakan di Laboratorium Botani (ruang penelitian in vitro), Jurusan Biologi, FMIPA, Universitas Lampung dari Desember 2015 sampai dengan Februari 2016. Penelitian dilaksanakan dalam rancangan acak lengkap dengan 5 perlakuan dan 5 ulangan. Perlakuan adalah penambahan asam salisilat ke dalam medium Murashige and Skoog (MS) dengan konsentrasi 0 ppm (kontrol), 40 ppm, 50 ppm, 60 ppm, dan 70 ppm. Satuan percobaan adalah planlet pisang ketan yang ditanam pada medium MS yang telah ditambah asam salisilat dengan berbagai konsentrasi. Data dianalisis ragam dan jika berbeda nyata dilanjutkan dengan uji BNT pada taraf nyata $5 \%$.

Persiapan medium tanam dan seleksi. Medium yang digunakan adalah MS padat dengan penambahan Benzyl Amino Purin (BAP). Setelah medium dicairkan, kemudian disterilisasi selama 15 menit. Medium MS yang sudah disterilkan kemudian ditambah asam salisilat (AS) dengan konsentrasi 0 ppm (kontrol), 40 ppm, 50 ppm, 60 ppm, dan 70 ppm.

Penanaman planlet dalam medium seleksi asam salisilat. Eksplan yang digunakan berupa planlet steril. Planlet-planlet dari botol kultur dikeluarkan dengan scalpel steril dan satu-persatu diletakkan di atas cawan petri berdiameter $10 \mathrm{~cm}$, kemudian planlet dipilah satu-satu, setelah itu ditanam pada masing-masing botol kultur yang berisi medium perlakuan yang telah ditentukan. Masing-masing konsentrasi dilakukan 5 kali ulangan dan setiap ulangan terdiri dari 2 eksplan pisang ketan dalam setiap botol kultur.

Analisis Aktivitas Enzim Peroksidase. Aktivitas enzim peroksidase dianalisis dengan metode Saravanan et al. (2004). Di tabung reaksi dibuat campuran 1,5 mL 0,05 M pirogalol, 0,5 mL ekstrak enzim dari daun planlet pisang ketan, dan $0,5 \mathrm{~mL} 1 \% \quad \mathrm{H}_{2} \mathrm{O}_{2}$. Campuran diendapkan dalam suhu kamar dan dimasukkan ke dalam kuvet berukuran $0,5 \mathrm{~mL}$. Absorbansi diukur dengan spektrofotometer UV pada panjang gelombang $(\lambda) 420 \mathrm{~nm}$ dan dibaca dari nol, dengan ulangan tiap sampel sebanyak 3 kali. Aktivitas enzim dihitung dalam U/mg/min. Satu unit adalah aktivitas berubahnya Optimal Density (OD) $420 \mathrm{~nm}$ pada spektrofotometer per menit.

\section{HASIL DAN PEMBAHASAN}

Aktivitas enzim peroksidase daun planlet pisang ketan yang di tanam pada medium Murashige and Skoog (MS) dengan penambahan berbagai konsentrasi asam salisilat di sajikan pada Tabel 1.

Tabel 1. Aktivitas enzim peroksidase daun planlet pisang ketan yang tidak diimbas (kontrol) dan telah diimbas asam salisilat (40, 50, 60, dan $70 \mathrm{ppm})$

\begin{tabular}{cc}
\hline Konsentrasi Asam Salisilat (ppm) & Aktivitas enzim peroksidase (U/mg/min) \\
\hline 0 (Kontrol) & $0,171 \pm 3,333 \mathrm{E}-07^{\mathrm{a}}$ \\
40 & $0,246 \pm 3,333 \mathrm{E}-07^{\mathrm{b}}$ \\
50 & $0,316 \pm 3,333 \mathrm{E}-07^{\mathrm{c}}$ \\
60 & $0,132 \pm 1,111 \mathrm{E}-07^{\mathrm{d}}$ \\
70 & $0,227 \pm 7,778 \mathrm{E}-07^{\mathrm{e}}$ \\
\hline
\end{tabular}

Keterangan : Angka yang diikuti oleh huruf yang sama tidak berbeda nyata pada taraf 5\%. 
Muslimah, I dkk : Aktivitas Enzim Peroksidase Daun Planlet Pisang Ketan (Musa paradisiaca L.) Hasil Pengimbasan..

Berdasarkan data yang ditampilkan pada Tabel 1 menunjukkan bahwa penambahan asam salisilat pada medium MS dengan berbagai konsentrasi berpengaruh nyata terhadap aktivitas enzim peroksidase. Uji BNT pada taraf nyata 5\% menunjukkan bahwa aktivitas enzim peroksidase daun planlet pisang ketan pada konsentrasi asam salisilat 40 ppm, 50 ppm, 60 ppm, dan 70 ppm berbeda nyata terhadap kontrol dan terhadap perlakuan lainnya.

Hasil penelitian menunjukkan bahwa pengimbasan asam salisilat terhadap planlet pisang ketan memberikan pengaruh positif terhadap aktivitas enzim peroksidase. Aktivitas enzim peroksidase mengalami peningkatan secara optimum pada konsentrasi asam salisilat $50 \mathrm{ppm}$. Hasil penelitian ini didukung oleh penelitian Nurcahyani et al. (2014) yang menyatakan bahwa terjadi peningkatan aktivitas enzim peroksidase pada planlet vanili (Vanilla planifolia Andrews) yang terimbas asam fusarat.

Selain itu, hasil penelitian ini sejalan dengan Susilowati (2015) yang menyatakan bahwa aktivitas enzim peroksidase pada planlet anggrek bulan (Phalaenopsis amabilis (L.) BI.) yang diimbas asam salisilat secara in vitro menunjukkkan peningkatan yang signifikan dibandingkan dengan kontrol (0 ppm). Yanti (2011) melaporkan bahwa terjadi peningkatan variasi aktivitas enzim peroksidase pada bibit pisang kepok yang diberi perlakuan mutagen Ethyl Methane Sulphonate (EMS) secara in vitro. Menurut Agrios (2005), tanaman yang peka tidak mengalami perubahan atau bahkan mengalami penurunan aktivitas enzim peroksidase dibandingkan dengan tanaman dalam keadaan sehat, sedangkan tanaman yang tahan akan mengalami peningkatan.

Campbell dan Jane (2008) menyatakan bahwa enzim peroksidase merupakan enzim yang berperan penting dalam biosintesis lignin. Tahapan polimerisasi lignin melibatkan enzim peroksidase yang diduga secara langsung berkaitan dengan peningkatan ketahanan fisik tanaman terhadap infeksi patogen maupun kerusakan fisik (Phabiola dan Khalimi, 2012).

\section{KESIMPULAN}

Hasil dari pengimbasan asam salisilat pada medium MS dengan konsentrasi 40 ppm, 50 ppm, 60 ppm, dan $70 \mathrm{ppm}$ berpengaruh nyata terhadap kandungan enzim peroksidase. Aktivitas enzim peroksidase mengalami peningkatan secara optimum pada konsentrasi asam salisilat $50 \mathrm{ppm}$.

\section{SARAN}

Penggunaan asam salisilat pada konsentrasi 50 ppm dianjurkan sebagai agen penyeleksi ketahanan planlet pisang ketan terhadap Fusarium oxysporum f.sp cubense.

\section{DAFTAR PUSTAKA}

Agrios, G.N. 2005. Plant Pathology, $5^{\text {th }} e d$. Elsevier Academic Press. California.

Campbell, N.A \& Jane B.R. 2008. BIOLOGI Jilid 2 Edisi Kedelapan. Erlangga. Jakarta.

Dimyati, A., I Djatnika, C. Hermanto, N. Nasir, and A. Hasyim. 2000. Current Research Activities on Banana Disease and Pests in Indonesia. Proc. At The 10 $0^{\text {th }}$ INIBAP-ASPNET. Bangkok. pp 110- 122.

Megia, R. 2005. Musa sebagai Model Genom [Review]. Hayati. 12 (4). pp 167- 170.

Mulyani, N., Suprapto, dan Hendra, J. 2008. Teknologi Budidaya Pisang. Balai Besar Pengkajian dan Pengembangan Teknologi Pertanian. 26 p.

Nurcahyani, E., B. Hadisutrisno, I. Sumardi, dan E. Suharyanto. 2014. Identifikasi galur planlet vanili (Vanilla planifolia Andrews) Resisten terhadap infeksi Fusarium oxysporum f.sp. vanillae hasil seleksi in vitro dengan asam fusarat. Prosiding Seminar Nasional: "Pengendalian Penyakit Pada Tanaman Pertanian Ramah Lingkungan". Perhimpunan Fitopatologi Indonesia Komda Joglosemar-Fakultas Pertanian UGM. ISBN 978- 602-71784-0-3./2014 pp 272- 279. 
Jurnal Penelitian Pertanian Terapan

Phabiola, T.A. dan K. Khalimi. 2012. Pengaruh Aplikasi Formula Pantoea agglomerans Terhadap Aktivitas Antioksidan dan Kandungan Klorofil Daun Tanaman Strowberi. Jurnal Agrotrop. 2(2). pp 125-131.

Predieri, S. 2001. Mutation inductin and tissue culture in improving fruits. Plant Cell Tiss. Org. Cult 64. pp 185- 210.

Saravanan, T., R. Bhaskaran, and M. Muthusamy. 2004. Pseudomonas fluorescens Induced Enzymological Changes in Banana Roots (cv. Rasthali) against Fusarium Wilt Disease. Plant Pathology Journal. 3. pp 72-80.

Semangun, H. 1989. Penyakit- penyakit Tanaman Hortikultura di Indonesia. Gadjah Mada University Press. Yogyakarta.

Sunarjono, H. 2004. Budidaya Pisang dengan Bibit Kultur Jaringan. Penebar Swadaya. Jakarta.

Suryanti, Chinta, Y.D., dan Sumardiyono, C. 2009. Pengimbasan Ketahanan Pisang terhadap Penyakit Layu Fusarium dengan Asam Salisilat In Vitro. Jurnal Perlindungan Tanaman Indonesia. 15 (2). pp 90- 95.

Susilowati, E. 2015. Seleksi Planlet Anggrek Bulan (Phalaenopsis amabilis (L.) BI.) dengan Asam Salisilat secara In Vitro terhadap Aktivitas Enzim Peroksidase dan Kandungan Klorofil. (Skripsi). Universitas Lampung.

Yanti, Y. 2011. Aktivitas Peroksidase Mutan Pisang Kepok dengan Ethyl Methane Sulphonate (EMS) secara In Vitro. Jurnal Natur Indonesia. 14 (1). pp 32-36. 